\title{
Nematode resistance to five anthelmintic classes in naturally infected sheep herds in Northeastern Brazil
}

Resistência de nematódeos a cinco classes de anti-helmínticos em rebanhos de ovinos naturalmente infectados no Nordeste do Brasil

Francisca Flávia da Silva ${ }^{1}$; Hermano Manoel Francisco Figueiredo Bezerra²; Thais Ferreira Feitosa²; Vinícius Longo Ribeiro Vilela ${ }^{2 *}$

${ }^{1}$ Programa de Pós-graduação em Medicina Veterinária, Universidade Federal de Campina Grande - UFCG, Patos, PB, Brasil

${ }^{2}$ Departamento de Medicina Veterinária, Instituto Federal da Paraíba - IFPB, Sousa, PB, Brasil

Received March 14, 2018

Accepted August 21, 2018

\begin{abstract}
This study aimed to evaluate the occurrence of nematode resistance to anthelmintics on sheep herds from the semi-arid region of Paraíba, Northeastern Brazil. Fecal Egg Count Reduction Test (FECRT) was carried out on 20 properties. In each herd, 30 animals were divided into five groups containing six animals each: group I, treated with albendazole $10 \%, 4 \mathrm{mg} / \mathrm{kg}$; group II, ivermectin $0.08 \%, 0.2 \mathrm{mg} / \mathrm{kg}$; group III, closantel $10 \%, 10 \mathrm{mg} / \mathrm{kg}$; group IV, levamisole hydrochloride $5 \%, 5 \mathrm{mg} / \mathrm{kg}$; and group V, monepantel $2.5 \%, 2.5 \mathrm{mg} / \mathrm{kg}$. All treatments were administered orally as a single dose. Fecal samples were collected on days zero and 10 after treatment, to perform FECRT and coprocultures. Multiresistance was observed in all the properties; $95 \%$ had high resistance to albendazole, $85 \%$ to ivermectin, $80 \%$ to closantel, $40 \%$ to levamisole, and $45 \%$ to monepantel. On property 15 , where monepantel was ineffective, a second FECRT for this anthelmintic was carried out 4 months after the first, resulting in $75 \%$ efficacy. Immediately after the FECRT result, two ewes were euthanized and necropsied, and Haemonchus contortus, Trichostrongylus axei, Trichostrongylus colubriformis, Oesophagostomum columbianum, and Trichuris ovis were recovered. It was concluded that the resistance of sheep gastrointestinal nematodes to antthelmintic, including monepantel, is high.
\end{abstract}

Keywords: Amino-acetonitrile derivative, Haemonchus contortus, farming sheep, FECRT, anthelmintic treatment.

\section{Resumo}

O objetivo deste estudo foi avaliar a ocorrência de resistência de nematódeos a anti-helmínticos em rebanhos ovinos do semiárido da Paraíba, Nordeste do Brasil. Testes de Redução na Contagem de Ovos Fecais (TRCOF) foram conduzidos em 20 propriedades. Em cada rebanho, 30 animais foram selecionados e foram divididos em cinco grupos contendo seis animais cada: grupo I, tratado com albendazol $10 \%, 10 \mathrm{mg} / \mathrm{kg}$; grupo II, ivermectina $0,08 \%, 0,2 \mathrm{mg} / \mathrm{kg}$; grupo III, closantel 10\%, $10 \mathrm{mg} / \mathrm{kg}$; grupo IV, cloridrato de levamisol $5 \%, 5 \mathrm{mg} / \mathrm{kg}$; grupo $\mathrm{V}$, monepantel 2,5\%, 2,5 mg $/ \mathrm{kg}$. Todos os tratamentos foram administrados via oral, em dose única. Amostras fecais foram coletadas nos dias zero e 10 após os tratamentos, para a realização do TRCOF e coproculturas. Multirresistência foi observada em todas as propriedades; $95 \%$ dos rebanhos obtiveram alta resistência ao albendazole, $85 \%$ a ivermectina, $80 \%$ ao closantel, $40 \%$ ao levamisole, e $45 \%$ a monepantel. Na propriedade 15, onde o monepantel foi ineficaz, um segundo TRCOF foi conduzido para este fármaco 4 meses após o primeiro, resultando em 75\% de eficácia. Imediatamente após o resultado do TRCOF, duas ovelhas foram eutanaziadas e necropsiadas, e Haemonchus contortus, Trichostrongylus axei, Trichostrongylus colubriformis, Oesophagostomum columbianum, e Trichuris ovis foram recuperados. Concluiu-se que a resistência dos nematódeos gastrintestinais de ovinos aos anti-helmínticos, incluindo o monepantel, é alta.

Palavras-chave: Derivados de amino-acetonitrila, Haemonchus contortus, ovinocultura, TRCOF, tratamento anti-helmíntico.

\footnotetext{
*Corresponding author: Vinícius Longo Ribeiro Vilela. Departamento de Medicina Veterinária, Instituto Federal da Paraíba - IFPB, Av. Presidente Tancredo Neves, s/n, Jardim Sorrilândia, CEP 58800-970, Sousa, PB, Brasil. e-mail: vilelavlr@yahoo.com.br
} 


\section{Introduction}

Sheep production occupies a prominent place in the Brazilian Northeast, where producers use their products and by-products in food and commerce, generating stability and development for the region. However, several factors restrict the production and productivity of these animals, including nutritional problems and inadequate management practices in sanitary hygiene, especially the poor hygiene conditions that favor the increase of the population of gastrointestinal parasites, mainly $H$. contortus. This parasite is considered of great epidemiological importance due to its high resistance to anthelmintics (IDRIS et al., 2012).

The main form of controlling parasitic diseases is the use of chemical compounds with a broad spectrum of action; the producers mostly administer anthelmintics empirically (CEZAR et al., 2010). Among the most used drugs for parasitic control are benzimidazoles (albendazole, fenbendazole, and oxfendazole), milbemycins (moxidectin), avermectins (ivermectin), imidazothiazoles (levamisole hydrochloride), and salicylanilides (closantel sodium) (BORGES, 2003; VIEIRA et al., 2014). In addition, the anthelmintic resistance by $H$. contortus was particularly alarming in many studies all over Brazil (SALGADO \& SANTOS, 2016), including semi-arid region of the Paraíba State (RODRIGUES et al., 2007; LIMA et al., 2010; MELO et al., 2013; VILELA et al., 2016).

The irrational use of anthelmintics has been contributing to the resistance of gastrointestinal endoparasites of small ruminants, whose drugs are mostly available in the market. Monepantel, in turn, belongs to a new class of anthelmintics, the Amino-Acetonitrile Derivatives (DAA), which acts on gastrointestinal parasites resistant to all classical anthelmintic agents (KAMINSKY et al., 2008). According to Baker et al. (2012), monepantel showed a $100 \%$ efficacy against multiresistant $H$. contortus in sheep. Mederos et al. (2014) and Van den Brom et al. (2015) observed early resistance involving $H$. contortus in flocks of sheep from Uruguay and Holland, respectively. Likewise, Martins et al. (2017) observed that sheep helminths, especially $H$. contortus, are already resistant to monepantel in a sheep herd located in the state of São Paulo.

However, there were no studies in Brazil that evaluated the efficacy of monepantel in different herds of naturally infected sheep. Therefore, the present study aimed to evaluate the action of monepantel and other anthelmintics on gastrointestinal nematodes of sheep of the semi-arid region of Brazil.

\section{Material and Methods}

The experiment was carried out in 20 sheep-producing properties of the Paraíba semi-arid region between July and December 2016 (Figure 1). Thirty animals from each farm were used amounting to a total of 600 sheep of both sexes, with no defined racial pattern, with no anthelmintic treatment for at least 3 months and presenting a count of eggs per gram of feces $(\mathrm{EPG})>500$. Subsequently, the animals were identified individually and randomly distributed into five groups composed of six animals each: group I, treated with albendazole $10 \%$ (4 mg/kg; Ibazole $10 \%{ }^{\circledR}$; Ibasa); group II,

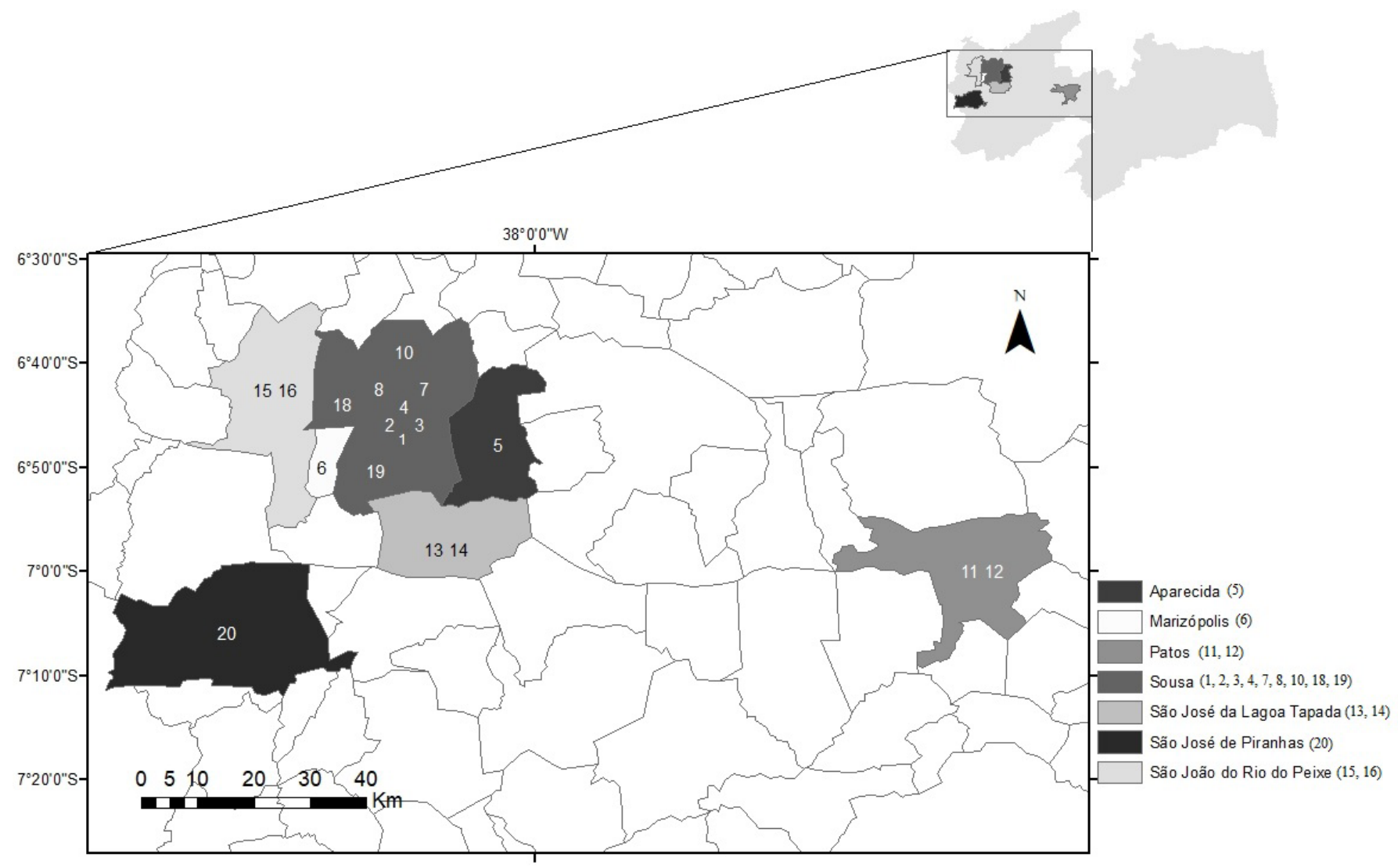

Figure 1. Georeferenced sheep farms from the Sertão region, Paraíba state, Brazil. 
treated with ivermectin $0.08 \%(0.2 \mathrm{mg} / \mathrm{kg}$; Ivomec Solução $\mathrm{Oral}^{\circledR}$; Merial); group III, treated with closantel $10 \%(10 \mathrm{mg} / \mathrm{kg}$; Diantel ${ }^{\circledR}$; Hipra); group IV, treated with levamisole hydrochloride $5 \%$ (5 mg/kg; Ripercol L Soluçáo ${ }^{\circledR}$; Fort Dodge); and group V, treated with monepantel 2.5\% (2.5 mg/kg; Zolvix ${ }^{\circledR}$; Novartis). All treatments were carried out with a single dose, administered orally, according to the manufacturers' recommendations.

Fecal samples were collected individually and directly from the rectal ampulla, and were subsequently placed in plastic bags, identified, kept refrigerated in an isothermal box, and promptly sent to the Veterinary Parasitology Laboratory (VPL) of the Instituto Federal da Paraíba (IFPB), Sousa-PB, for analyses.

Similarly, counting of EPG was performed according to Gordon \& Whitlock (1939) and coprocultures according to Roberts \& O'Sullivan (1950). The evaluation of the Fecal Egg Count Reduction Test (FECRT) was performed according to Coles et al. (1992). Such procedures were performed on day 0 and on day 10 after administration of anthelmintics.

The evaluation of the efficacy of the drugs was based on the Technical Regulation of Ordinance No. 48/1997 of the Ministry of Agriculture, Livestock and Food Supply (MAPA) for chemical substances with antiparasitic activity, using the following criteria: (1) highly effective, when it reduces the parasite load by more than 98\%; (2) effective, with a 90-98\% reduction; moderately effective, with a $80-89 \%$ reduction; and insufficiently active, with a reduction of $<80 \%$ (BRASIL, 1997).

The reduction percentage $(\mathrm{PR})$ of the fecal egg count was estimated by the following equation:

$$
\mathrm{PR}=100 \cdot\left(1-\mathrm{X}_{\mathrm{d} 10} / \mathrm{X}_{\mathrm{d} 0}\right)
$$

Where $\mathrm{X}_{\mathrm{d} 10}$ is the arithmetic mean of the egg count for the group on day 10 , and $\mathrm{X}_{\mathrm{d} 0}$ is the arithmetic mean for the group on day 0 (before treatment).

Information related to the size of the properties and the number of animals in the herds were obtained for the calculation of the stocking rate (Animal Unit (AU)/ha; $1 \mathrm{AU}=450 \mathrm{~kg}$ of animal body weight). To associate the stocking rate to anthelmintic resistance, univariable analysis was performed using the Fisher's exact test, and variables that presented $P \leq 0.20$ were used for multivariable logistic regression, performed using the BioEstat 5.0 software (AYRES et al., 2007).

In one of the properties that presented high resistance to monepantel (Prop. 15), new FECRT for this drug was performed 4 months later in 20 sheep for resistance confirmation purposes.

On the day following the confirmation of resistance, the two animals with the highest parasitic load were purchased, slaughtered, and necropsied according to international standards established by the World Association for the Advancement of Veterinary Parasitology (WAAVP) and described by Vercruysse et al. (2001). Therefore, the gastrointestinal tract of sheep was separated by its anatomical segments (abomasum, small intestine, and large intestine), isolated, and subsequently separated by double ligatures with cotton thread. The abomasum was opened at its greatest curvature and the contents stored in a container, where a $10 \%$ aliquot was preserved in 5\% formol. The mucosa of the whole abomasum was submerged in saline solution at $39{ }^{\circ} \mathrm{C}$ for $6 \mathrm{~h}$. Subsequently, an aliquot of $10 \%$ of the digested material was preserved in 5\% formalin. Similar procedures were also performed with respect to the small and large intestines. The counting and identification of the recovered helminths were carried out according to Ueno \& Gonçalves (1998).

\section{Results}

Multiresistance was observed in all evaluated properties, with 30\% (6/20) showing resistance against two drugs, $40 \%$ $(8 / 20)$ presenting resistance to three drugs, $25 \%$ (5/20) showing resistance to four, and 5\% (1/20) presenting resistance to all evaluated drugs (Table 1).

When categorizing properties based on drug efficacy, we observed that levamisole was highly effective in 30\% (6/20) of the properties, while albendazole showed the least effectiveness, being classified as insufficiently active in 90\% (18/20) of the properties. It was noted that monepantel was highly effective in only $15 \%(3 / 20)$ of the properties (Table 2$)$.

It was observed the presence of three gastrointestinal nematodes genera after larval recovery from the coprocultures, Haemonchus sp., Oesophagostomum sp. and Trichostrongylus spp., with no great variation of their percentages between the groups, nor between the samples before and after treatments (Day 0 and Day 10, respectively), as demonstrated in Figure 2.

It was observed that the most used breeding system was the semi-intensive (10/20), followed by extensive (9/20), and intensive (1/20). The breeds of sheep raised were Santa Inês (50\%), SRD (40\%), Morada Nova (5\%), and Dorper (5\%). The average number of sheep per farm was 85 animals.

Among the active principles used, ivermectin was the most cited (13/20), followed by albendazole (6/20), closantel $(3 / 20)$, and levamisole $(3 / 20)$. The anthelmintics were administered every 60 days in $50 \%$ of the properties, every 90 days in $15 \%$ of the properties, every 120 days in $25 \%$ of the herds, and every 240 days in $10 \%$ of the properties studied.

There was no influence $(P>0.20)$ of the stocking rate on the anthelmintic resistance (efficacy $<80 \%$ ). In the five properties with $<10$ ha (0.648 AU/ha), of the 25 anthelmintic tests, $15(60 \%)$ showed resistance. Similarly, in the four properties with $>50$ ha (0.154 AU/ha), 13 (65\%) anthelmintic trials demonstrated high degree of resistance, with monepantel being ineffective in $75 \%$ (3/4) of these trials (Table 3 ).

At property 15, new TRCOF for monepantel was performed 4 months after the first, resulting in a $75 \%$ efficacy. It was observed that the two necropsied animals had a high number of nematodes in their gastrointestinal tract after monepantel treatment (Table 4). $H$. contortus presented the highest infection intensity, with an average of 505 adult nematodes, followed by $T$. colubriformis, with an average of 175 nematodes.

\section{Discussion}

The present study was the first to test the anthelmintic efficacy of monepantel against gastrointestinal nematodes in different sheep herds in Northeastern Brazil. This drug was insufficiently 
Table 1. Efficacy of anthelmintics on sheep gastrointestinal nematodes in the semi-arid region of Paraíba, Brazil.

\begin{tabular}{|c|c|c|c|c|c|}
\hline Property & Albendazole (\%) & Levamisole (\%) & Closantel (\%) & Ivermectin (\%) & Monepantel (\%) \\
\hline 1 & 31 & 100 & 76 & -21 & 100 \\
\hline 2 & 47 & 74 & 67 & -33 & 98 \\
\hline 3 & 19 & 60 & 53 & 93 & 68 \\
\hline 4 & -3 & 98 & 73 & 83 & 84 \\
\hline 5 & 36 & 100 & 77 & 51 & 98 \\
\hline 6 & 47 & 100 & 59 & 63 & 100 \\
\hline 7 & 63 & 90 & 66 & -14 & 88 \\
\hline 8 & 75 & 97 & 93 & 40 & 98 \\
\hline 9 & 71 & 99 & 95 & 28 & 86 \\
\hline 10 & 80 & 87 & 74 & 29 & 92 \\
\hline 11 & 45 & 79 & 90 & 31 & 77 \\
\hline 12 & 53 & -5 & 50 & 93 & 88 \\
\hline 13 & 50 & 90 & 30 & 69 & 58 \\
\hline 14 & 73 & 78 & 13 & 58 & 78 \\
\hline 15 & 94 & 96 & 44 & 57 & 68 \\
\hline 16 & 50 & 100 & 56 & 66 & 94 \\
\hline 17 & 50 & 100 & 86 & 100 & 98 \\
\hline 18 & -17 & 77 & 56 & -41 & 91 \\
\hline 19 & 70 & 97 & 25 & 83 & 91 \\
\hline 20 & -60 & 81 & 94 & -133 & 100 \\
\hline Average & 20.4 & 84.9 & 63.8 & 35.1 & 87.7 \\
\hline
\end{tabular}

Table 2. Percentage of properties by category of efficacy of anthelmintics on gastrointestinal nematodes of sheep in the Paraíba semi-arid region, Brazil, according to Brazilian Ministry of Agriculture, ordinance No. 48/1997.

\begin{tabular}{cccccc}
\hline \multirow{2}{*}{ Categories of effectiveness } & \multicolumn{5}{c}{ Anthelmintic } \\
\cline { 2 - 6 } & Albendazole (\%) & Levamisole (\%) & Closantel (\%) & Ivermectin (\%) & Monepantel (\%) \\
\hline Highly Effective (>98\%) & - & 30 & - & 5 & 15 \\
Effective (90-98\%) & 5 & 30 & 20 & 10 & 10 \\
Moderately Effective (80-89\%) & 5 & 10 & 5 & 75 & 20 \\
Insufficiently Active (<80\%) & 90 & 30 & 75 & 75 \\
\hline
\end{tabular}

Table 3. Number of insufficiently active (efficacy < 80\%) anthelmintics according to the area and stocking rate of sheep producing properties in the Paraíba semi-arid region.

\begin{tabular}{|c|c|c|c|c|c|c|c|c|}
\hline \multirow{2}{*}{ Property area - ha } & \multirow{2}{*}{ No of properties (\%) } & \multirow{2}{*}{ Stocking rate (AU/ha) } & \multicolumn{5}{|c|}{ Resistance } & \multirow{2}{*}{$P$ value* } \\
\hline & & & A & $\mathbf{L}$ & $\mathrm{C}$ & I & $\mathbf{M}$ & \\
\hline$\leq 10$ & $5(25)$ & 0.648 & 5 & 2 & 4 & 3 & 1 & \multirow{4}{*}{0.56} \\
\hline $11-24$ & $6(30)$ & 0.559 & 6 & 3 & 3 & 4 & 1 & \\
\hline $25-49$ & $5(25)$ & 0.149 & 4 & 1 & 5 & 5 & - & \\
\hline$\geq 50$ & $4(20)$ & 0.154 & 3 & 1 & 3 & 3 & 3 & \\
\hline
\end{tabular}

A, albendazole; C, closantel; I, ivermectin; L, levamisole; M, monepantel. *Univariate analysis. P>0.20, multivariate analysis was not performed. No - number; $\mathrm{AU}$ - animal unit

active (efficacy $<80 \%)$ in $25 \%(5 / 20)$ of the analyzed properties, showing resistance in the region. Cintra et al. (2016) reported for the first time the occurrence of resistance to monepantel in Brazil associated with $T$. colubriformis, in naturally infected sheep of the Experimental Farm of the Catholic University of Paraná (PUC-PR), with an efficacy of $-21.5 \%$. Mederos et al. (2014) reported for the first time the occurrence of resistance to monepantel in Latin America, associated with Haemonchus sp. in two properties in Uruguay. Van Den Brom et al. (2015) demonstrated a 0\% efficacy by FECRT in a sheep farm in the Netherlands, related to the genus Haemonchus sp.

Monepantel was introduced in the Brazilian market with the promise of $100 \%$ efficacy in the treatment of gastrointestinal strongyles in sheep, including those that have already developed resistance to other active principles. However, even with the use of the drug for the first time in the studied properties, anthelmintic resistance cases were found. It is well described that the entire herd treatments at short intervals, leads to the selection of strains of 
Albendazole

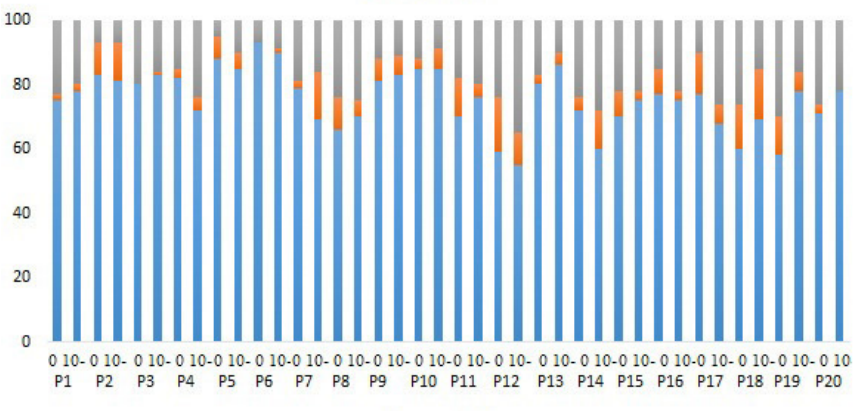

Closantel

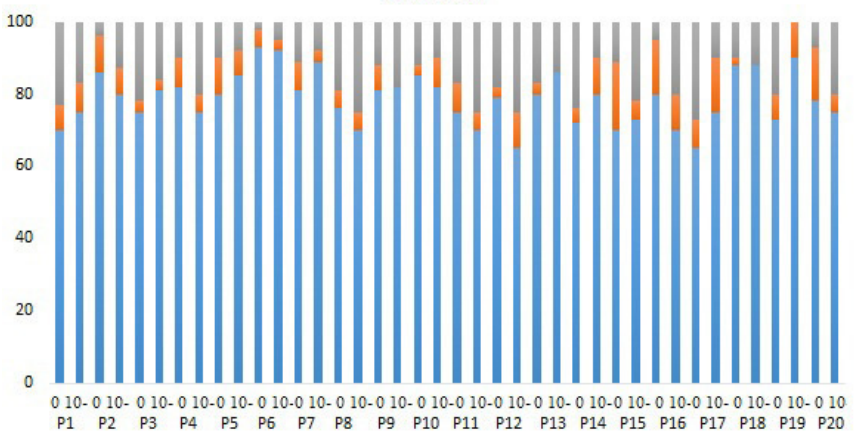

Levamisole
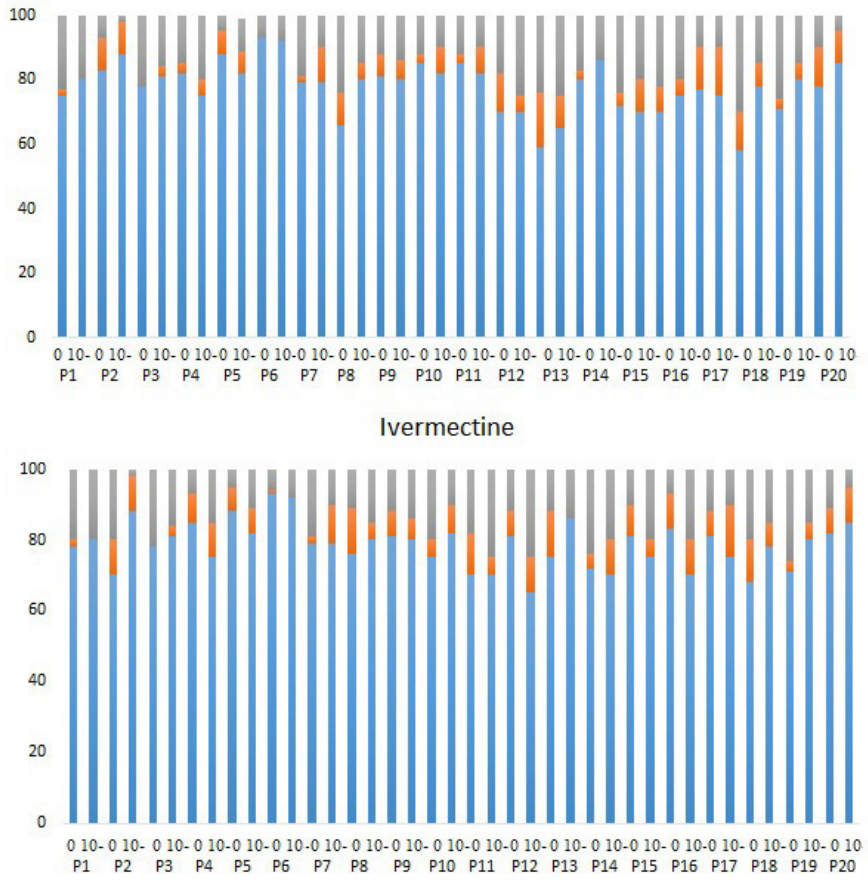

Monepantel

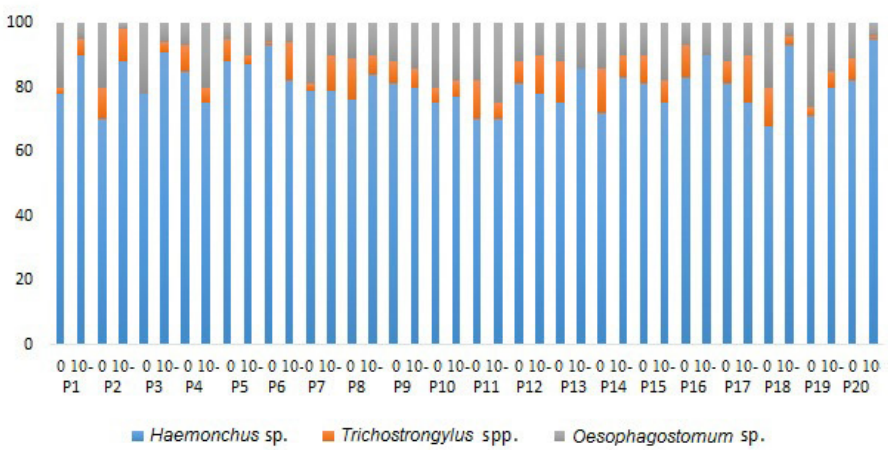

Figure 2. Percentage of nematodes by genus, farm and treatment recovered from coprocultures (Days 0 and 10) of sheep in the semi-arid region of Paraíba, Brazil.

Table 4. Species of gastrointestinal nematodes recovered from sheep submitted to necropsy after Fecal Egg Count Reduction Test for monepantel in the Paraíba semi-arid region, Brazil.

\begin{tabular}{lcccc}
\hline \multicolumn{1}{c}{ Species } & Sex & Animal 4 & Animal 12 & Average \\
\hline Haemonchus contortus & Female & 120 & 530 & 325 \\
& Male & 70 & 290 & 180 \\
Trichostrongylus axei & Female & 50 & 160 & 105 \\
& Male & 10 & 70 & 40 \\
Trichostrongylus & Female & 160 & 80 & 120 \\
colubriformis & Male & 50 & 60 & 55 \\
Oesophagostomum & Female & - & - & - \\
columbianum & Male & - & 10 & 5 \\
Trichuris ovis & Female & - & - & - \\
& Male & - & 10 & 5 \\
Total & & 460 & 1210 & - \\
Average & & - & - & 835 \\
\hline
\end{tabular}

resistant parasites, generates contaminant residues in the environment, and increases production costs (SUTHERLAND et al., 2008; ZAROS et al., 2014).

Bartley et al. (2004) emphasized that the anthelmintic resistance of gastrointestinal nematodes of small ruminants has been observed worldwide. In this study, multiresistance was observed in all evaluated farms, wherein $95 \%$ of farms had high resistance to albendazole, $85 \%$ to ivermectin, $80 \%$ to closantel, $40 \%$ to levamisole, and $45 \%$ to monepantel. In another study involving 35 sheep farms in the state of São Paulo, resistance to albendazole and ivermectin was observed in $100 \%$ of the farms studied, while $92 \%$ showed resistance to closantel and 53\% to levamisole (VERÍSSIMO et al., 2012). High anthelmintic resistance was also reported by Melo et al. (2013), when evaluating the efficacy of ivermectin and levamisole in 13 sheep farms in the Agreste of the State of Paraíba, with a reduction of only $30.9 \%$ and $93 \%$, respectively. 
When categorizing properties regarding drug efficacy, it was observed that levamisole was highly effective in 30\% of the analyses. Albendazole was the one that showed the least effectiveness, being classified as insufficiently active in $90 \%$ of the properties. It was also noted that monepantel was highly effective in only $40 \%$. Although monepantel is a novel molecule with no history of use in the animals of this herd, this drug has not shown to be effective on gastrointestinal nematodes. According to Oliveira et al. (2017), who evaluated the anthelmintic resistance in sheep flocks in southern Brazil, the resistance to at least three anthelmintic agents was reported on all properties, being Monepantel not effective in $18 \%$ of the tested flocks, confirming that parasitic resistance can be established very soon after the anthelmintic treatment with new molecules, mainly when alternative program of parasite control is not performed.

In all coprocultures, the most prevalent helminth genus was Haemonchus sp., corroborating with Vieira et al. (2014), who identified (79.9\%) of Haemonchus sp. in sheep in the semi-arid region of Paraíba State. The successive anthelmintic treatments performed on the properties lead to a higher selection pressure for Haemonchus, making it the most prevalent in most researches (VILELA et al., 2012, 2016). It is plausible that this worm acquires faster resistance due to its high biotic potential, great genetic variability, and for having the allele that causes the increase of the resistance to a drug (BLACKHALL et al., 1998).

Vieira et al. (2014) observed that the most relevant risk factor for the development of helminthiasis in their study was the farm area, because it defines the area available for grazing animals. Properties with many animals and little pasture area, which are the most abundant type in the Sertão region of Paraiba, tend to have high prevalence of gastrointestinal helminthiasis, because the animals are more prone to reinfection. On the other hand, in the present study, because so many mistakes of anthelmintic management were observed in the evaluated herds, especially underdoses and fast alternation of active principles, the resistance was so high that the stocking rate may not have influence it.

In the second stage of the study, after new FECRT for monepantel at property 15 , it was again insufficiently active (75\% efficacy). After the recovery of adult helminths, it was possible to diagnose resistance of the species $H$. contortus, T. axei, T. colubriformis, O. columbianum and T. ovis. In São Paulo, Martins et al. (2017) diagnosed a resistance to monepantel $2.5 \%$ using a critical test (parasitological necropsy) in sheep, in which the compound was ineffective against $H$. contortus (24.65\%). Cintra et al. (2016) have detected resistance $(-21.5 \%)$ of $T$. colubriformis to monepantel. When evaluating sheep in New Zealand, Scott et al. (2013) described the first report of resistance to monepantel of Teladorsagia spp., Trichostrongylus spp., and Oesophagostomum spp., being also ineffective against Capillaria spp., Trichuris spp., and Strongyloides spp. Still in that study was reported that the continued presence after treatment of Capillaria spp., Trichuris spp. and Strongyloides spp. do not necessarily indicate resistance in these parasites since they have never been included in any registered claim for Zolvix ${ }^{\circledR}$. There may in fact be no intrinsic activity of monepantel against these nematodes (RUFENER et al., 2010).

Several factors contribute to the development of resistance to the drugs used to control gastrointestinal nematodes, such as the uncontrolled use of anthelmintics due to the lack of knowledge of the producers, the poor management practices, and the ease of acquiring these medicines. According to Vilela et al. (2012), the high anthelmintic resistance observed in studies carried out in the semi-arid region of the Brazilian Northeast is due to the fact that it is a common practice to treat massively the entire herd of small ruminants four to six times a year.

\section{Conclusion}

The resistance of the gastrointestinal nematodes of sheep from the semi-arid region of Paraíba, Northeastern Brazil, to the anthelmintics, including monepantel, is high. The most resistant helminth was $H$. contortus. The incorrect management that is commonly practiced in the herds of the region tends to aggravate the multiresistance observed in all evaluated properties.

\section{Acknowledgements}

The authors wish to acknowledge the financial support received from Coordination for the Improvement of Higher Education Personnel-CAPES, Brazil. The experiment was approved by the Ethics Committee of the Universidade Federal de Campina Grande - UFCG, Patos-PB, Brazil, on May 23, 2016.

\section{References}

Ayres M, Ayres JRM, Ayres DL, Santos AS. BioEstat 5.0: aplicaçōes estatísticas nas áreas de ciências biológicas e médicas. 4. ed. Belém: Sociedade Civil Mamirauá; 2007.

Baker KE, George SD, Stein PA, Seewald W, Rolfe PF, Hosking BC. Efficacy of monepantel and anthelmintic combinations against multipleresistant Haemonchus contortus in sheep, including characterisation of the nematode isolate. Vet Parasitol 2012; 186(3-4): 513-517. http://dx.doi. org/10.1016/j.vetpar.2011.11.060. PMid:22169404.

Bartley DJ, Jackson F, Jackson E, Sargison N. Characterisation of two triple resistant field isolates of Teladorsagia from Scottish lowland sheep farms. Vet Parasitol 2004; 123(3-4): 189-199. http://dx.doi.org/10.1016/j. vetpar.2004.06.018. PMid:15325045.

Blackhall WJ, Pouliot JF, Prichard RK, Beech RN. Haemonchus contortus: selection at a glutamate-gated chloride channel gene in ivermectin-and moxidectin-selected strains. Exp Parasitol 1998; 90(1): 42-48. http:// dx.doi.org/10.1006/expr.1998.4316. PMid:9709029.

Borges CCL. Atividade in vitro de anti-helmínticos sobre larvas infectantes de nematódeos gastrintestinais de caprinos, utilizando a técnica de coprocultura quantitativa (Ueno, 1995). Parasitol Latinoam 2003; 58(3-4): 142-147.

Brasil. Ministério da Agricultura, Pecuária e Abastecimento - MAPA. Portaria no 48, de 12 de maio de1997. Regulamento técnico para licenciamento e/ou renovação de licença de produtos antiparasitários de uso veterinário. Diário Oficial da República Federativa do Brasil, Brasília, maio 1997.

Cezar AS, Toscan G, Camillo G, Sangioni LA, Ribas HO, Vogel FSF Multiple resistance of gastrointestinal nematodes to nine different drugs 
in sheep flock in southern Brazil. Vet Parasitol 2010; 173(1-2): 157-160. http://dx.doi.org/10.1016/j.vetpar.2010.06.013. PMid:20619543.

Cintra MCR, Teixeira VN, Nascimento LV, Sotomaior CS. Lack of efficacy of monepantel against Trichostrongylus colubriformis in sheep in Brazil. Vet Parasitol 2016; 216: 4-6. http://dx.doi.org/10.1016/j. vetpar.2015.11.013. PMid:26801587.

Coles GC, Bauer C, Borgsteede FH, Geerts S, Klei TR, Taylor MA, et al. World Association for the Advancement of Veterinary Parasitology (W.A.A.V.P) methods for the detection of anthelmintic resistance in nematodes of veterinary importance. Vet Parasitol 1992; 44(1-2): 35-44. http://dx.doi.org/10.1016/0304-4017(92)90141-U. PMid:1441190.

Gordon HM, Whitlock HV. A new technique for counting nematode eggs in sheep faeces. J Counc Sci Ind Res 1939; 12(1): 50-52.

Idris A, Moors E, Sohnrey B, Gauly M. Gastrointestinal nematode infections in German sheep. Parasitol Res 2012; 110(4): 1453-1459. http://dx.doi.org/10.1007/s00436-011-2648-1. PMid:21979784.

Kaminsky R, Ducray P, Jung M, Clover R, Rufener L, Bouvier J, et al. A new class of anthelmintics effective against drug-resistant nematodes. Nature 2008; 452(7184): 176-180. http://dx.doi.org/10.1038/nature06722. PMid:18337814.

Lima WC, Athayde ACR, Medeiros GR, Lima DSD, Borburema JB, Santos EM, et al. Nematóides resistentes a alguns anti-helmínticos em rebanhos caprinos no Cariri Paraibano. Pesq Vet Bras 2010; 30(12): 1003-1009. http://dx.doi.org/10.1590/S0100-736X2010001200001.

Martins AC, Bergamasco PLF, Felippelli G, Tebaldi JH, Moraes MFD, Testi AJP, et al. Haemonchus contortus resistance to monepantel in sheep: fecal egg count reduction tests and randomized controlled trials. Semina: Ciênc Agrár 2017; 38(1): 231-238. http://dx.doi.org/10.5433/16790359.2017v38n1p231.

Mederos AE, Ramos Z, Banchero GE. First report of monepantel Haemonchus contortus resistance on sheep farms in Uruguay. Parasit Vectors 2014; 7(1): 598. http://dx.doi.org/10.1186/s13071-014-0598-z. PMid:25515711.

Melo LRB, Vilela VLR, Feitosa TF, Almeida Neto JL, Morais DF. Anthelmintic resistance in small ruminants from the Semiarid of paraíba state, Brazil. Ars Vet 2013; 29(2): 104-108. http://dx.doi.org/10.15361/21750106.2013v29n2p104-108.

Oliveira PA, Riet-Correa B, Estima-Silva P, Coelho AC, Santos BL, Costa MAP, et al. Multiple anthelmintic resistance in Southern Brazil sheep flocks. Rev Bras Parasitol Vet 2017; 26(4): 427-432. http://dx.doi. org/10.1590/s1984-29612017058. PMid:29069158.

Roberts FHS, O'Sullivan JP. Methods for egg counts and larval cultures for strongyles infesting the gastro-intestinal tract of cattle. Aust J Agric Res 1950; 1(1): 99-102. http://dx.doi.org/10.1071/AR9500099.

Rodrigues AB, Athayde ACR, Rodrigues OG, Silva WW, Faria EB. Sensibilidade dos nematóides gastrintestinais de caprinos a anti-helmínticos na mesorregiāo do Sertão Paraibano. Pesq Vet Bras 2007; 27(4): 162-166. http://dx.doi.org/10.1590/S0100-736X2007000400006.
Rufener L, Keiser J, Kaminsky R, Maser P, Nilsson D. Phylogenomics of ligand-gated ion channels predicts monepantel effect. PLoS Pathog 2010; 6(9): e1001091. http://dx.doi.org/10.1371/journal.ppat.1001091. PMid:20838602.

Salgado JA, Santos CP. Overview of anthelmintic resistance of gastrointestinal nematodes of small ruminants in Brazil. Rev Bras Parasitol Vet 2016; 25(1): 3-17. http://dx.doi.org/10.1590/S1984-29612016008. PMid:26982560.

Scott I, Pomroy B, Kenyon PR, Smith G, Adlington B, Moss A. Lack of efficacy of monepantel against Teladorsagia circuncicta and Trichostrongylus colubriformis. Vet Parasitol 2013; 198(1-2): 166-171. http://dx.doi. org/10.1016/j.vetpar.2013.07.037. PMid:23953148.

Sutherland IA, Damsteegt A, Miller CM, Leathwick DM. Multiple species of nematodes resistant to ivermectin and a benzimidazole-levamisole combination on a sheep farm in New Zealand. NZ Vet J2008; 56(2): 6770. http://dx.doi.org/10.1080/00480169.2008.36810. PMid:18408792.

Ueno H, Gonçalves PC. Manual para diagnóstico das helmintoses de ruminantes. 4. ed. Japan: Japan International Cooperation Agency; 1998.

Van den Brom R, Moll L, Kappert C, Vellema P. Haemonchus contortus resistance to monepantel in sheep. Vet Parasitol 2015; 209(3-4): 278280. http://dx.doi.org/10.1016/j.vetpar.2015.02.026. PMid:25770852.

Vercruysse J, Holdsworth P, Letonja T, Barth D, Conder G, Hamamoto $\mathrm{K}$, et al. International harmonisation of anthelmintic efficacy guidelines. Vet Parasitol 2001; 96(3): 171-193. http://dx.doi.org/10.1016/S03044017(00)00443-X. PMid:11240092.

Veríssimo CJ, Niciura SCM, Alberti ALA, Rodrigues CFC, Barbosa CMP, Chiebao DP, et al. Multidrug and multispecies resistance in sheep flocks from Sao Paulo state, Brazil. Vet Parasitol 2012; 187(1-2): 209216. http://dx.doi.org/10.1016/j.vetpar.2012.01.013. PMid:22341829.

Vieira VD, Vilela VLR, Feitosa TF, Athayde ACR, Azevedo SS, Souto DVO, et al. Sheep gastrointestinal helminthiasis in the Sertão region of Paraíba State, Northeastern Brazil: prevalence and risk factors. Rev Bras Parasitol Vet 2014; 23(4): 488-494. http://dx.doi.org/10.1590/S198429612014089 . PMid:25517527.

Vilela VL, Feitosa TF, Braga FR, Araújo JV, Souto DV, Santos HE, et al. Biological control of goat gastrointestinal helminthiasis by Duddingtonia flagrans in a semi-arid region of the northeastern Brazil. Vet Parasitol2012; 188(1-2): 127-133. http://dx.doi.org/10.1016/j.vetpar.2012.02.018. PMid:22436426.

Vilela VLR, Feitosa TF, Braga FR, Araújo JV, Santos A, Morais DF, et al. Coadministration of nematophagous fungi for biological control over gastrointestinal helminths in sheep in the semiarid region of northeastern Brazil. Vet Parasitol 2016; 221: 139-143. http://dx.doi.org/10.1016/j. vetpar.2016.03.027. PMid:27084486.

Zaros LG, Neves MRM, Benvenuti CL, Navarro AMC, Sider LH, Coutinho LL, et al. Response of resistant and susceptible Brazilian Somalis crossbreed sheep naturally infected by Haemonchus contortus. Parasitol Res 2014; 113(3): 1155-1161. http://dx.doi.org/10.1007/s00436-0143753-8. PMid:24425452. 